\title{
Financial Structure and Operating Efficiency of Housing Cooperative Societies
}

\author{
Kalundu Kimanzi, PhD Candidate \\ Mirie Mwangi, PhD, Associate Professor \\ Duncan Elly Ochieng, (PhD, Lecturer) \\ Josephat Lishenga, (PhD, Associate Professor) \\ University of Nairobi, School of Business \\ Department of Finance and Accounting, Nairobi, Kenya
}

Doi:10.19044/esj.2019.v15n28p109 URL:http://dx.doi.org/10.19044/esj.2019.v15n28p109

\begin{abstract}
Housing co-operatives contribute to the social-economic growth of a country. They are voluntary in concept and owner-user and based on members' loyalty. Therefore, this study sought to establish the relationship between financial structure and operating efficiency on housing co-operative Societies in Nairobi City County, Kenya. The data collection form was used to record data of all the elements of financial structure and operating efficiency from audited financial statements. Housing co-operatives, which constituted $50.3 \%$ of response rate were analysed using a two-stage process: data envelopment analysis and regression analysis. The first stage involved the use of DEA model to compute the efficiency scores, which were regressed in the second stage using linear regression analysis. The results from DEA output indicate that most of the housing co-operatives were inefficient while the regression results indicated that a positive and significant relationship existed between financial structure and operating efficiency. Therefore, this study recommends that housing co-operatives should formulate strategies that would grow their operations to reduce operational costs and enhance management efficiency. Besides, there is a need for housing co-operatives' boards of directors to make prudent investment decisions that would help members' maximize social and economic goals.
\end{abstract}

Keywords: Financial Structure, Operating Efficiency, Housing co-operative Societies, Data Envelopment Analysis

\section{Introduction}

The co-operatives sub-sector plays a critical role in the growth of an economy of a country, and their impact cannot be underestimated (Marwa \& 
Aziakpono, 2016). Besides contributing to sound financial sector, cooperatives are essential in stabilizing the economy of a country (Sufian, 2011). As a result, it is important to monitor and regulate the sector's operations to minimize the economic downturn. However, the growth of the sub-sector has experienced an unprecedented level of competition leading to the instability of many housing co-operatives (Marr \& Turbora, 2011). This, therefore, becomes a fundamental concern of any corporate finance manager in selecting a financial structure that maximises the performance of a firm. Consequently, an optimal mix of debt and equity finance could mitigate financial frictions due to asymmetric information (Jensen \& Meckling, 1976) thus maximising operating efficiency. Therefore, failure to monitor the levels of the firm's finance mix could increase operating costs (inputs). Marr and Tubaro (2011) and Apergis and Rezitis (2004) link efficient operation of financial intermediaries to an optimal mix of factors relating to production, for instance, labour and capital. Further, financial constraints and factors related to the attributes of the managers could influence the choice of finance (Bretos \& Marcuello, 2017).

As noted by Marr and Tubaro (2011) operating efficiency provides information about the optimal use of resources, and failure to measure and monitor performance could lead to a crisis in an organization. The link between operating efficiency and financial structure as advanced by Alsas and Florysiak (2011) holds that the firm's management should utilise the capital invested to acquire the assets for a firm. According to Al-Najjar \& Hussainey, 2011; Hailu, Jeffrey, \& Goddard, (2007); Wang (2016), financing of cooperatives is extensively discussed theoretically and empirically, however, the literature on financial structure of housing co-operatives is scanty and financing of co-operatives largely remains a central question in corporate finance. Kassim, Ishak, and Manaf (2013) observed that past empirical literature has provided relatively little consensus on the link between financial structure and performance.

The sections that follow present the empirical review on financial structure and operating efficiency. The research hypotheses are incorporated in this section along with the research methodology and results of the study.

\section{Literature Review}

Co-operative researchers have used a variety of theories among them governance theory and property rights theory (Yu \& Nilsson, 2019). Though the broader aspects of co-operatives are both social and economic benefits, the theories in this study presume that members pursue individual benefits. The pecking order theory and theory of social capital are underpinning theories that explore the financing mix and operating efficiency of housing cooperatives. Considering the financing mix, co-operatives are founded on 
equity accumulation and equity redemption without share price considerations (Wang, 2016). Notwithstanding, co-operatives face similar market forces as investor-owned firms. Thus the choice of co-operatives' capital is different from investor-owned firms ((Li, Jacobs, \& Artz, 2015). While the issues of financial structure appear to be ignored in housing co-operatives, several studies have documented its importance on the performance of firms. According to Leary and Roberts (2010), the pecking order theory is hypothetical and researchers have not achieved consensus about the assertion of the theory on the assumptions of financing. Co-operatives' funds mostly come from members and very little from external sources (Li et al., 2015).

Generally, firms are financed by all equity or all debt or a combination of the two strands of finance (Vo \& Nguyen, 2014). In the context of the financial sector, financial structure and capital structure constitute different concepts. In that, finance structure includes short-term finances in the finance mix while capital structure constitutes only share capital and long-term loans as sources of finance. Due to ownership structure, Baxamusa, Sunilmohanty, and Rao (2015) pronounced that co-operatives experience unique agency costs and information asymmetry because of multiple objectives that hinder them from accessing loan facilities. Co-operatives are less competitive in the financial market because their objectives are not driven by the motive of profit maximization, thus highly vulnerable to government policy changes and regulation.

The users of services from the co-operatives contribute to the financing of the firm's activities through members' deposits and share capital. Other sources of co-operatives' finance comprise retained margins, member loans, and short- and long-term finances (Wang, 2016; Baarda, 2006). Core capital consists of share capital and reserves. This represents shareholders' funds for the co-operative society. The co-operative societies set aside earnings as statutory reserves, including general and revenue reserves collectively referred to as institutional capital. The institutional capital acts as a buffer to cater for asset losses that could arise from adverse economic cycles thus safeguarding members from operational risk and capital inadequacy (Robb, Smith, \& Webb, 2010; World Council of Credit Unions [WOCCU], 2003).

Operating efficiency is an outcome of optimal utilization of resources (Mozaffari, Gerami, \& Jablonsky, 2014). According to Coelli, Rao, O'Donnell, and Battese, (2005) firms should have the capacity to produce maximum outputs from a minimum level of inputs to be efficient. For that reason, to be efficient, the firm should have the ability to produce goods or services in the most cost-effective manner (Kuosmanen \& Johnson, 2017). This implies that a decision-making unit has the option of increasing operating efficiency by increasing the output or decreasing input prices or even 
increasing the scale of the production process to reduce the average cost per unit.

\section{Data Envelopment Analysis}

The origin of DEA is traced from the work of Farrell (1957) who advocated for identification of an empirical efficient frontier for decisionmaking units (Banker, Charnes, \& Cooper, 1984). Charnes et al. (1978) developed DEA for application in the public sector and not-for-profit organizations where typical economic behavioural objectives of cost minimization and profit maximization are not relevant. The formulation of the DEA model is in line with linear programming techniques that envelop the observed inputs and outputs of DMUs. The efficiency of firms is measured by production frontier and non-parametric framework. Technical efficiency as alluded by Berger and Humphrey (1997) and Banker, et al. (1984) is the standard measure operating efficiency. Different studies have measured efficiency using ratios, data envelopment analysis and stochastic frontier analysis (Veenstra, Koolma, and Allers, 2016). This study applied data envelopment analysis as a managerial and performance measurement tool in calculating efficiency scores of housing co-operative societies since it does not consider the nature of the distribution of data set (Charnes, Cooper, \& Rhodes, 1978). The DEA model is superior to accounting ratio since it integrates multiple inputs and output(s), thus able to identify the sources and levels of inefficiency for each decision-making unit (Mozaffari et al., 2014). The following were the steps involved in developing the model:

Consider having a population of $\mathrm{s}$ co-operative societies, that is DMU1, DMU2, ..., DMUs. Each DMU produces m outputs while consuming $n$ inputs. Rewriting the input matrix $X=[x i j, i=1,2, \ldots, n, j=1,2, \ldots, s]$ and an output matrix $Y=[y i j, i=1,2, \ldots, m, j=1,2, \ldots, s]$.The s-th line - i.e. Xs and Ys of these matrixes thus shows quantified inputs/outputs of DMUs. The efficiency rate (ratio) of such a DMU was expressed as:

$$
h_{s}=\frac{\sum_{i=1}^{m} u_{i} y_{i s}}{\sum_{j=1}^{n} v_{j} x_{j s}}
$$

Where: $v j, j=1,2, \ldots, n$, are weights assigned to $j$-th input, ui, $i=1,2, \ldots, m$, are weights assigned to i-th output. $h_{s}$ is efficiency ratio; $u_{i}$ is the output weight; $y_{i s}$ is the amount of the output $(\mathrm{m})$ produced by a specific housing cooperative society $(\mathrm{s}) ; v_{j}$ is the input weight; $x_{j s}$ is the amount of input (n) used by a specific housing co-operative society (s); $i$ runs from one (1) to $\mathrm{m} ; j$ runs from one (1) to $n$.

In DEA models, the s DMUs are evaluated; where each DMU takes n different inputs to produce $\mathrm{m}$ different outputs. The essence of DEA models in 
measuring the efficiency of DMUs by maximising its efficiency rate, however, subject to the condition that the efficiency rate (score) of any other units in the population must not be greater than 1. The models must include all characteristics considered, i.e. the weights of all inputs and outputs must be greater than zero. The efficiency maximising problem was defined as follows:

$\operatorname{Max} \frac{\sum_{i=1}^{m} u_{i} y_{i s}}{\sum_{j=1}^{n} v_{j} x_{j s}}$

Subject to

$\frac{\sum_{i=1}^{m} u_{i} y_{i s}}{\sum_{j=1}^{n} v_{j} x_{j s}} \leq 1, k=$

$1,2 \ldots, n$

Where: $u i \geq \varepsilon i=1,2, \ldots, s$ and $v j \leq \varepsilon j=1,2, \ldots, m$

The first inequality (equation 3) implies that the score of a DMU should not exceed unity (1) meaning a firm's efficiency cannot be more than $100 \%$, and the second inequality (equation 4) indicates that the weights are non-negative and determined entirely from the output and input data of all DMUs in the dataset. The weights of the variables in DEA are optimized automatically thus presenting the firm in the best possible way (Coelli et al. (2005). The DEA does not work with negatives values for inputs and outputs, and the number of observation for all the firms should equal.

\section{Financial Structure and Operating Efficiency}

Financing of firms could be equity or debt-financed or a mix of sources of finance (Vo \& Nguyen, 2014). A study by Li et al. (2015) shows that cooperatives relying heavily on equity financing and loans contributed to mixed results in the short-run due to the financial constraints of the co-operatives. Hailu et al. (2007) did a study focusing on capital structure, firm size and operating efficiency of co-operatives in Canada on a sample of 42 cooperatives from 115 different co-operatives in Canada from 1984-2001. The unrelated stochastic frontier model was applied in the study. The findings reported a significant cost inefficiency in all co-operatives, but co-operatives that had a sound financial structure in terms of equity capital exhibited variations in the cost efficiency and improved efficiency. The samples were from agriculture and petroleum sectors thus it was difficult to generalize the findings due to unrelated technology and processes in their operations.

In a study by Rajan and Zingales (1995) which investigated public firms in the G-7 countries showed that firms using retained earnings and less debt were profitable than debt-financed firms. Further examination on foreign 
evidence, the theoretical foundations of the observed associations of the findings is unclear for pecking order theory. The theory advocates for use of retained earnings first, then debt and lastly other finances.

A study by Lang and Welzel (1996) who analyzed financial data of 757 German co-operative banks from 1989 to 1992 . The findings indicate that low capitalized banks benefited from higher total factor productivity (TFP) growth to highly capitalized banks, in that big German banking sector did not indicate any evidence of economies of scale. They found that merging small inefficient banks did not reap any benefits of economies of scale or eliminate inefficiencies of smaller banks due to failure to respond to input prices and external environmental variables that are not diversifiable through merger. Wang (2016) examined the optimal financial structure of co-operatives incorporating stochastic interest rates. The results showed that changes in business risk were sensitive to optimal equity-to-asset ratio but less sensitive to the changes in the interest rate risk. This places firms at a better negotiating position when borrowing funds for operating activities. As stated by Robb et al. (2010), for co-operatives to remain efficient they must have the ability to raise enough equity capital to meet their long-term investment needs. A study by Worthington (1999) examined the technical efficiency of Australian credit unions. The results showed that credit unions that were using bank loans were relatively efficient.

Kipesha (2012) looked at the efficiency scores of 35 microfinance institutions and co-operatives using the production approach. The results showed that microfinance institutions in East Africa, especially Kenya and Rwanda had higher average efficiency scores. The results of the study did not have peer co-operatives to benchmark with inefficient decision-making units. Based on the empirical literature studies on housing co-operatives are limited to financial structure and operating efficiency. A study by Othman et al. (2014) assessed the productivity and efficiency of co-operatives in Malaysia. The study looked at 56 co-operative groups out of 70 where the analysis used a two-stage model, the DEA and Tobit regression model for one (2011) year. The inputs of the study were members, turnover, and profit as output. The findings of Othman et al.'s study indicated that an increase in turnover and profit of co-operatives contributed to an increase in co-operative efficiency scores. However, referring to co-operative groups under the study only $19.6 \%$ were operating at efficient and less than $2 \%$ of big co-operatives were in the successful category. A study by Veenstra et al. (2016) determined the effect of scale and mergers on the efficiency of Dutch housing corporations where DEA and stochastic frontier analysis were used on a panel data of twelve years from 2001 to 2012. The findings disclosed that housing corporations generally operated under diseconomies of scale and the reasons for high technical efficiency were not attributable to the merger of housing 
corporations. Considerations in this study infer that factors affecting technical efficiency would vary across DMUs depending on the scale of operations and poor management practices. Consequently, this study tested the null hypothesis:

$\mathbf{H}_{\mathbf{0}}$ The relationship between financial structure and operating efficiency of housing co-operative societies in Nairobi City County is not significant.

\section{Methodology}

Research Design

The descriptive cross-sectional study design was adopted since the overall objective of the study was to assess the relationship of variables of study units over five years. The descriptive cross-sectional survey determines the kind of relationship among variables by dividing a sample into appropriate subgroups (Zikmund, 2003). Several studies comprising Bereźnicka (2013), and Irungu (2007) used descriptive cross-sectional survey to test for the board effectiveness and performance across firms.

\section{Sample and Data Sources}

The components of financial structure and input and output data were obtained from financial statements. The study population was housing cooperative societies operating in Nairobi City County, Kenya. The sampling frame was prepared from the register of co-operatives at the state department of co-operatives (GoK, 2016). This target population was 173 housing cooperative societies that had operated for more than five years as of December 31, 2016. A multistage sampling technique was followed in choosing the sample since the technique applies a combination of probability sampling techniques at several steps (Zikmund, 2003).

Measures of variables

DEA methodology determined efficiency ratios for each housing cooperative society where the efficiency ratio was computed using STATA software equipped with DEA. The DEA formula was given as efficiency ratio $=\frac{\sum_{i=1}^{m} u_{i} y_{i s}}{\sum_{j=1}^{n} v_{j} x_{j s}}$, Where the efficiency ratio (score) was determined as the summation of the weights of the amount of output divided by the summation of the sum of the weights of the amount of inputs (Banker et al., 1984). The efficiency ratio is the constant returns to technical efficiency, $v j, j=1,2 \ldots n$, are weights assigned to $j$-th input, ui, $i=1,2 \ldots \mathrm{m}$, are weights assigned to the i-th output. ; $u_{i}$ is the output weight; $y_{i s}$ is the amount of the output $(\mathrm{m})$ produced by a specific housing co-operative society $(\mathrm{s}) ; v_{j}$ is the input weight; $x_{j s}$ is the amount of input (n) used by a specific housing co-operative society (s); $i$ runs from one (1) to $\mathrm{m} ; j$ runs from one (1) to $\mathrm{n}$. The basis of selection of the variables of this study was by the intermediation approach combined with expert knowledge and accepted practices (Othman, Mansor, \& Kari, 
2014). This study defined the inputs to include labour costs, operating expenses, and cost of the investment; while output was total revenue. The financial structure components comprised; share capital, institutional capital, members' deposits, non-interest-bearing liabilities and interest-bearing liabilities. The operationalization of the independent variables was determined by obtaining the percentage of each component to core capital plus liabilities (firm value).

\section{Data analysis}

The descriptive and inferential statistics presented data analysis for financial structure and constant returns to scale technical efficiency (crs-te) scores. DEA programmed in STATA computed the crs-te scores. The model measures the performance of organisations' relative efficiency using preselected inputs and outputs (Dyson \& Shale, 2010). However, to establish the hypothesized relationship the study used a two-stage model that is data envelopment analysis (DEA) and linear regression in the analysis (Simar \&Wilson, 2015; Othman, Mansor, \& Kari, 2014).

\section{Diagnostic tests}

The Shapiro-Wilk test results reported significance effect $(\mathrm{p}<0.05)$ thus indicating that the sample data was not from normally distributed data set. In addition, the results for Breusch-Pagan/Cook-Weisberg test indicated that chi-square was $\chi^{2}(1)=0.01,(p>0.05)(0.9220)$. This implied that the regression residuals were homoscedasticity thus the existence of heteroscedasticity did not occur in the regression estimation. Checking for multicollinearity, the variance inflation factor (VIF) for the variables reported values of less than 10 and above 0.1 for tolerance thus suggesting that there was no multicollinearity problem (Denis, 2011). Lastly, based on the Hausman test, the chi-square statistics was 32.90 and a p-value of 0.0000 , therefore we failed to accept the null hypothesis and concluded that pooled OLS regression was the appropriate model for estimation.

\section{Hypotheses testing}

The test of the hypothesized relationship between the independent variables and the dependent variable was through simple and multiple regression analysis. The main regression function that tested the hypotheses was $Y=\alpha_{0}+\beta_{1} X_{1}+\varepsilon$ where operating efficiency $(\mathrm{Y})=\mathrm{f}$ (constant $+\mathrm{FS}+$ error term). In the regression model $\beta_{1}$ represents coefficient and the $X_{1}$ individual component of financial structure.

\section{Results and Discussion}

Tables 1 and 2 presents descriptive statistics and regression model, respectively for 435 observations $(\mathrm{N})$ from 87 housing co-operatives. Tables 1 displays the descriptive statistics of the variables of the study. 
Table 1: Descriptive statistics

\begin{tabular}{|c|c|c|c|c|c|c|c|c|}
\hline Component & $\mathrm{N}$ & Mean & SD & $\mathrm{CV}$ & Min & Max & Skewness & Kurtosis \\
\hline Share capital & 435 & $8,792,854$ & $34,173,684$ & 3.9 & 2240 & $45,8971,697$ & 10 & 122 \\
\hline $\begin{array}{l}\text { Institutional } \\
\text { Capital }\end{array}$ & 435 & $29,604,817$ & $252,936,643$ & 8.5 & $-81,328,176$ & $3,167,441,449$ & 9.3 & 94 \\
\hline Members Deposits & 435 & $55,300,176$ & $157,663,428$ & 2.9 & 32,500 & $1,372,965,712$ & 4.8 & 29 \\
\hline $\begin{array}{c}\text { Non-interest } \\
\text { Bearing Liabilities }\end{array}$ & 435 & $87,061,258$ & $895,919,694$ & 10 & 7,900 & $17,047,512,064$ & 18 & 347 \\
\hline Interest Bearing & 435 & $97,241,562$ & $41,419,4471$ & 4.3 & 108,061 & $4,282,967,179$ & 8.9 & 89 \\
\hline CRS-TE scores & 435 & 0.6776 & 0.3652 & 1.0 & 0.37 & 1 & 0.5405 & 4.563 \\
\hline
\end{tabular}

Table 1 reports that the components of financial structure and efficiency scores did not vary greatly from the mean. Based on the standard deviation (SD) the efficiency score across housing co-operatives also did not vary greatly from the mean and similarly to dispersion when the coefficient of variation was used. This infers that the performance of the housing cooperatives did not vary across decision-making units. The results on the components of financial structure, the housing co-operatives had uneven distribution away from the mean. The interest-bearing liabilities and institutional capital had the greatest dispersion from the mean, implying that firms use of trade payables and accrued expenses, and statutory reserves were highly dissimilar across housing co-operative societies.

Hypothesis test

Table 2 presents the results of regression analysis that tested the hypothesis for the relationship between financial structure and operating efficiency. The test of the hypothesis was for each component and for all components constituting financial structure (see model 6).

Table 2: Regression Results on the Relationship between Financial Structure and Operating Efficiency

\begin{tabular}{|c|c|c|c|c|c|c|}
\hline & $\begin{array}{l}\text { Model 1 } \\
\text { CRS_TE }\end{array}$ & $\begin{array}{l}\text { Model 2 } \\
\text { CRS_TE }\end{array}$ & $\begin{array}{l}\text { Model } 3 \\
\text { CRS_TE }\end{array}$ & $\begin{array}{l}\text { Model } 4 \\
\text { CRS_TE }\end{array}$ & $\begin{array}{l}\text { Model } 5 \\
\text { CRS_TE }\end{array}$ & $\begin{array}{l}\text { Model } 6 \\
\text { CRS_TE }\end{array}$ \\
\hline Share Capital & $\begin{array}{l}0.0482^{* *} \\
(0.002)\end{array}$ & & & & & $\begin{array}{l}0.0429^{* *} \\
(0.007)\end{array}$ \\
\hline Institutional Capital & & $\begin{array}{l}0.00643^{* *} \\
(0.003)\end{array}$ & & & & $\begin{array}{l}0.00803^{*} \\
(0.011)\end{array}$ \\
\hline Members Deposits & & & $\begin{array}{l}-0.00698^{*} \\
(0.049)\end{array}$ & & & $\begin{array}{l}-0.0127^{* *} \\
(0.002)\end{array}$ \\
\hline Non-Interest Bearing & & & & $0.00133^{*}$ & & 0.000202 \\
\hline Liabilities & & & & $(0.027)$ & & $(0.816)$ \\
\hline Interest Bearing & & & & & $\begin{array}{l}-0.00230 \\
(0.311)\end{array}$ & $\begin{array}{l}-0.00131 \\
(0.589)\end{array}$ \\
\hline Constant & $\begin{array}{l}0.769^{* * *} \\
(0.000)\end{array}$ & $\begin{array}{l}0.771^{\text {**** }} \\
(0.000)\end{array}$ & $\begin{array}{l}0.776^{* * * *} \\
(0.000)\end{array}$ & $\begin{array}{l}0.772^{* * * *} \\
(0.000)\end{array}$ & $\begin{array}{l}0.773^{* * * *} \\
(0.000)\end{array}$ & $\begin{array}{l}0.773^{* * * *} \\
(0.000)\end{array}$ \\
\hline Observations & 435 & 435 & 435 & 435 & 435 & 435 \\
\hline$R^{2}$ & 0.021 & 0.021 & 0.009 & 0.011 & 0.0024 & 0.064 \\
\hline
\end{tabular}




\begin{tabular}{lllllll} 
Adjusted $R^{2}$ & 0.019 & 0.018 & 0.007 & 0.009 & 0.0001 & 0.053 \\
F-Stat & 9.410 & 9.121 & 3.895 & 4.939 & 1.027 & 5.862 \\
Degrees of Freedom & $(1,433)$ & $(1,433)$ & $(1,433)$ & $(1,433)$ & $(1,433)$ & $(5,429)$ \\
a p-value of F stat & 0.0000 & 0.0027 & 0.0491 & 0.0268 & 0.3115 & 0.0000 \\
\hline \multicolumn{2}{r}{$P$-values in parentheses * indicates level of significance, $* \mathrm{p}<0.10, * * \mathrm{p}<0.05, * * * \mathrm{p}<0.01$}
\end{tabular}

Observed in Table 2 are regression results for models (1) to (6). Model (1) estimated the hypothesized relationship concerning share capital and crste/operating efficiency. The findings indicate that share capital had a positive and significant effect on operating efficiency $[\beta=0.0482, \mathrm{P}<0.05(0.002)]$ at $5 \%$ level of significance: an indication that a one-unit increase in share capital contributed to an increase in operating efficiency by 0.0482 units. This presumes that housing co-operatives when sourcing for additional resources should prioritize funds from members' equity over other sources because it contributes the highest units in operating efficiency. These findings negate the agency theory's principle that debt-financed firms have fewer agency costs and are more efficient compared to equity-financed ones.

Model 2 displays the results of the association between the institutional reserve and technical efficiency. The results indicate a positive relationship between institutional reserves and operating efficiency $[\beta=0.00643, P<0.05$ ) $(0.003)]$ at $5 \%$ level of significance. The findings infer that a one-unit increase in the institutional capital contributed to an increase in operating efficiency by 0.00643 units. The inference drawn here is that housing co-operatives should prioritise the use of institutional capital in financing activities of the firms since a one-unit increase from this source of finance contributed to an increase in operating efficiency.

The results in model 3 present the findings on the members' deposits concerning operating efficiency. The outcomes reveal a significant but negative association between members' deposits and operating efficiency $\beta=$ $-0.00698, p<0.10(0.049)$ at a $10 \%$ level of significance. This led to the deduction that an increase in funding through members' deposit contributed to a decrease in operating efficiency, probably suggesting members' deposits was not prudently invested thus increased agency problems.

Model 4 gives the regression results of non-interest-bearing liabilities on operating efficiency. The analysis indicates that the results had a positivesignificant effect $\beta=0.00133, p<0.10(0.027)$ at a $10 \%$ level of significance between the two. Additionally, the findings suggest that a rise in non-interest liabilities contribute to positive changes in operating efficiency by 0.00133 units. Accordingly, housing co-operatives have an option of funding operations through trade payables and accrued expenses.

The findings in model 5 show that interest-bearing liabilities (loans and bank overdraft) had an insignificant and negative effect on operating efficiency $\beta=-0.00230, p>0.10(0.311)$ at $10 \%$ level of significance: 
indicating that loans and bank overdraft did have an insignificant effect on operating efficiency. This relationship fails to affirm the agency theory's principle that an increase in debt finance leads to a decrease in agency costs and ultimately good performance.

Model 6 represents the financial structure, which comprises the core capital (share capital and institutional capital) and liabilities (members' deposits, non-interest-bearing, and interest-bearing liabilities) in predicting operating efficiency. The model was a good fit in predicting operating efficiency $\mathrm{F}(5,429)=5.862, \mathrm{P}<0.05(0.0000)$. About model $1-5$, it was observed that upon inclusion of all components of financial structure in model 6 predictive power (adjusted $R^{2}$ ) greatly increased to 5.3\%. This indicates that financial structure contributed to variation in operating efficiency. Therefore, financial structure and operating efficiency had significant correlation thus the null hypothesis was rejected.

\section{Discussion and Implications}

The purpose of the study was to build on the empirical literature on financial structure and operating efficiency of housing co-operatives. The results from the DEA model established that the majority of housing cooperatives were inefficient. The findings revealed that $95.4 \%$ of housing cooperatives operating in Nairobi City County, Kenya were technically inefficient. The implication being that they were operating at increasing returns to scale or decreasing returns to scale. As a result, decision-making units (DMUs) could reduce their inputs by $32.24 \%$ while generating the same revenue. The information from descriptive statistics indicates that efficiency scores were not widely dispersed from the mean across housing co-operatives. Therefore, the study findings were not different from studies that had considered the firms operating from a similar geographical area. These findings concur with Worthington (1999) and $\mathrm{Li}$ et al. (2015) who found that firms that were not distinct and operated from comparable geographic area and had similar institutional characteristics reported efficiency scores that were not significantly different.

In the second stage analysis, the efficiency scores were regressed on the components of financial structure to determine the hypothesized relationship between financial structure and operating efficiency. The results of the study were inconsistent with theoretical literature. The relationship failed to uphold the agency theory's principle (Jensen and Meckling, 1976) in that an increase in debt finance when all other factors are held constant could lead to a decrease in agency costs and ultimately good performance. The coefficient for interestbearing liabilities was statistically insignificant and therefore did not have any effect on operating efficiency. Besides this, all other components of financial structure had a positive significant relationship except for members' deposits that were significant but inversely related to operating efficiency. Finally, 
considering all components jointly - a significant relationship existed between financial structure and operating efficiency. The finding implies that housing co-operatives should maintain ideal levels of share capital and institutional capital that keep operating costs at a bare minimum thus improving efficiency. Besides, the management of housing co-operatives should maintain ideal cash balances for members' deposits while investing the rest of the money into income-generating projects. This study, therefore, failed to accept the null hypothesis.

\section{Conclusion and recommendation}

Regarding the relationship between financial structure and operating efficiency, the results from the DEA model established that the majority of housing co-operatives were inefficient. As mentioned in the preceding section, the DEA model results established the root sources of inefficiencies across the housing co-operative societies in Nairobi City County. The findings exhibited technical efficiency scores of the sample housing co-operative societies that were not optimum. Consequently, the DMUs can reduce inputs while at the same time generating the similar income. The findings revealed that most of DMUs operating in Nairobi City County, Kenya were technically inefficient, the implication being that they were operating at both increasing returns to scale, decreasing returns to scale or constant returns to scale, probably because of poor management and wrong scale of operation. Therefore, housing cooperatives should devise ways of growing to build capacity and reduce operational costs to enhance economies of scale.

The findings from regression analysis show that financial structure and operating efficiency were positively related for most of the components of financial structure. Specifically, an increase in share capital and institutional capital would contribute to an increase in operating efficiency. This suggests that housing co-operatives with appropriate share capital and institutional capital would contribute to better performance. Whilst members' deposits had a significant and negative relationship. Therefore, monies received from the members should be invested wisely in income-generating projects. In conclusion, housing co-operatives' boards of directors should make prudent investment decisions to maximize members' economic and social benefits. The findings of this study may raise some important managerial implications concerning the optimization of investments and financial structure. They would provide empirical support for the importance of contextual factors in the relationship between financial structure and operating efficiency. The members involved in policy implementation can devise ways of optimizing resources and recommend areas of improvement towards attaining operating efficiency. They can use the findings to revise regulations on borrowing and control the registration of housing co-operatives in Kenya. 


\section{References:}

1. Al-Najjar, B., \& Hussainey, K. (2011). Revisiting the capital-structure puzzle: UK evidence. The Journal of Risk Finance, 12(4), 329-338.

2. Apergis, N., \& Rezitis, A. (2004). Cost structure, technological change, and productivity growth in the Greek banking sector. International Advances in Economic Research, 10(1), 1-15.

3. Baarda, J. R. (2006). Current Issues in Co-operative Finance and Governance. Washington, DC: US Department of Agriculture.

4. Banker, R. D., Charnes, A., \& Cooper, W. W. (1984). Some models for estimating technical and scale inefficiencies in data envelopment analysis. Management Science, 30(9), 1078-1092.

5. Baxamusa, M., Sunilmohanty, S., \& Rao, R. P. (2015). Information asymmetry about investment risk and financing choice. Journal of Business Finance and Accounting, 42(7-8), 947-964.

6. Berger, A. N., \& Humphrey, D. B. (1997). The efficiency of financial institutions: International survey and directions for future research. European Journal of Operational Research, 98(2), 175-212.

7. Bretos, I., \& Marcuello, C. (2017). Revisiting globalization challenges and opportunities in the development of co-operatives. Annals of Public and Co-operative Economics, 88(1), 47-73.

8. Charnes, A., Cooper, W. W., \& Rhodes, E. (1978). Measuring the efficiency of decision-making units. European Journal of Operational Research, 2(6), 429-444.

9. Coelli, T. J., Rao, D. S. P., O'Donnell, C. J., \& Battese, G. E. (2005). An introduction to efficiency and productivity analysis. Springer Science \& Business Media.

10. Denis, D. (2011). Multiple Linear Regression Using SPSS Part II. The University of Montana.

11. Dyson, R. G., \& Shale, E. A. (2010). Data envelopment analysis, operational research, in addition, uncertainty. Journal of Operational Research Society, 61(1), 25-34.

12. Elsas, R., \& Florysiak, D. (2011). Heterogeneity in the speed of adjustment toward target leverage. International Review of Finance, 11(2), 181-211.

13. Elsas, R., \& Florysiak, D. (2011). Heterogeneity in the speed of adjustment toward target leverage. International Review of Finance, 11(2), 181-211.

14. Farrell, M. (1957). The Measurement of Productive Efficiency. Journal of the Royal Statistical Society. Series A (General), 120(3), 253-290.

15. GoK (2016). Ministry of Industry, Trade, and Co-operatives: http:// www. Industrialization, go.ke. 
16. Hailu, G., Jeffrey, S. R., \& Goddard, E. W. (2007). Capital structure, firm size, and efficiency: the case of farm petroleum and animal feed co-operatives in Canada. Agricultural Finance Review, 67(2), 279293.

17. Irungu, S.M. (2007). The effect of top management teams on the performance of publicly quoted companies in Kenya. University of Nairobi: Unpublished PhD Thesis.

18. Jensen, M. C., \& Meckling, W. H. (1976). Theory of the firm: Managerial behaviour, agency costs, and ownership structure. Journal of Financial Economics, 3(4), 305-360.

19. Kassim, A. A. M., Ishak, Z., \& Manaf, N. A. A. (2013). Board effectiveness and company performance: Assessing the mediating role of capital structure decisions. International Journal of Business and Society, 14(2), 319-338.

20. Kipesha, E. F. (2012). Efficiency of microfinance institutions in East Africa: a data envelopment analysis. European Journal of Business and Management, 4(17), 77-88.

21. Kuosmanen, T., \& Johnson, A. (2017). Modeling joint production of multiple outputs in StoNED: Directional distance function approach. European Journal of Operational Research, 262(2), 792-801.

22. Lang, G., \& Welzel, P. (1996). Efficiency and technical progress in banking Empirical results for a panel of German co-operative banks. Journal of Banking \& Finance, 20(6), 1003-1023.

23. Leary, M. T., \& Roberts, M. R. (2010). The pecking order, debt capacity, and information asymmetry. Journal of Financial Economics, 95(3), 332-355.

24. Li, Z., Jacobs, K. L., \& Artz, G. M. (2015). The co-operative capital constraint revisited. Agricultural Finance Review, 75(2), 253-266.

25. Marr, A. \& Tubaro, P. (2011). Crisis in Indian microfinance and a way forward: Governance reforms and the Tamil Nadu model. Journal of International Development, 23(7), 996- 1003.

26. Marwa, N., \& Aziakpono, M. (2016). Technical and scale efficiency of Tanzanian saving and credit co-operatives. The Journal of Developing Areas, 50(1), 29-46.

27. Mozaffari, M. R., Gerami, J., \& Jablonsky, J. (2014). The relationship between DEA models without explicit inputs and DEA-R models. Central European Journal of Operational Research, 22(1), 1-12.

28. Othman, A., Mansor, N., \& Kari, F. (2014). Assessing the performance of co-operatives in Malaysia: an analysis of co-operative groups using a data envelopment analysis approach. Asian Pacific Business Review, 20(3), 484-505. 
29. Rajan, R. G., \& Zingales, L. (1995). What do we know about capital structure? Some evidence from international data. The Journal of Finance, 50(5), 1421-1460.

30. Robb, A. J., Smith, J. H., \& Webb, J. T. (2010). Co-operative capital: what it is and why our world needs it. In a paper for Euricse Conference on Financial Co-operative Approaches to Local Development through Sustainable Innovation, Trento, Italy (8-9).

31. Simar, L., \& Wilson, P. W. (2015). Statistical approaches for nonparametric frontier models: a guided tour. International Statistical Review, 83(1), 77-110.

32. Veenstra, J., Koolma, H. M., \& Allers, M. A. (2016). Scale, mergers, and efficiency: The case of Dutch housing corporations. Journal of Housing and the Built Environment, 31(2), 1-25.

33. Vo, D. H., \& Nguyen, V. T. Y. (2014). Managerial Ownership, Leverage and Dividend Policies: Empirical Evidence from Vietnam's Listed Firms. International Journal of Economics and Finance, 6(5), 274.

34. Wang, Y.C. (2016). The optimal capital structure in agricultural cooperatives under the revolving fund cycles. Agricultural Economics, 62(1), 45-50.

35. World Council of Credit Unions Inc. (WOCCU) (2003). Pearls monitoring system user's manual. http://www.woccu.org/pearls/support.

36. Worthington, A. (1999). Measuring technical efficiency of Australian credit unions. Manchester School, 67(2), 231-248.

37. Yu, L., \& Nilsson, J. (2019). Social Capital and Financial Capital in Chinese Co-operatives. Sustainability, 11(8), 2400-2415.

38. Zikmund, W. G. (2003). Business research methods. ( $7^{\text {th }}$ ed.) Indiana, United States of America: Thomson Publishers 